\title{
THE DEVELOPMENT OF A WEB-BASED INTEGRATED FINANCIAL INFORMATION SYSTEM AT PT. PURA BARUTAMA KUDUS
}

\author{
Andrean Richardo 1; Nina Setiyawati2* \\ Teknik Informatika ${ }^{1,2}$ \\ Universitas Kristen Satya Wacana \\ www.uksw.edu \\ andreanrichardoar@gmail.com 1;nina.setiyawati@uksw.edu ${ }^{2}$ \\ (*) Corresponding Author
}

\begin{abstract}
Pura Barutama Inc. is a printing and packaging company based in the city of Kudus, where its financial information such as pre-order reports, accounts receivable balance reports, invoice information, and income tax article 23, must be inquired manually to the finance department. So there are issues with access to the financial information that is directly linked to consumers and vendors, namely a lack of flexibility and productivity in marketing, tax, and purchasing departments. Therefore, this study aims to provide solutions to the problems by designing and building a webbased financial information system. This information system was designed using objectoriented modeling methods, namely the Unified Modeling Language (UML) method, and was built with the PHP programming language using the CodeIgniter framework and Oracle database which was directly connected to Pura Barutama Inc. This information system is expected to increase flexibility and efficiency in the marketing, taxation, and purchasing departments of the company's financial data management process and can obtain financial details without requesting the finance department.
\end{abstract}

Keywords: Financial Information System, Integrated, CodeIgniter, PHP, Oracle.

Abstrak-PT Pura Barutama merupakan perusahaan yang bergerak di bidang percetakan dan kemasan yang berada di Kota Kudus yang dimana untuk melihat informasi keuangan seperti laporan pre-order, laporan saldo piutang, informasi faktur, dan pajak penghasilan pasal 23 harus meminta secara manual kepada bagian keuangan. Sehingga terjadi permasalahan, yaitu kurangnya fleksibilitas dan efisiensi dari bagian marketing, perpajakan, dan bagian pembelian dalam mengakses informasi keuangan yang berhubungan langsung dengan customer maupun supplier. Maka dari itu, penelitian ini bertujuan untuk memberikan solusi dari permasalahan yang terjadi dengan merancang dan membangun sistem informasi keuangan berbasis web. Sistem informasi ini dirancang menggunakan metode pemodelan yang berorientasi objek yaitu metode Unified Modeling Language (UML) serta dibangun dengan bahasa pemrograman PHP menggunakan framework CodeIgniter dan basis data Oracle yang terhubung langsung ke PT Pura Barutama. Dengan adanya sistem informasi ini diharapkan dapat menambah fleksibilitas dan efisiensi pada bagian marketing, perpajakan, dan bagian pembelian dalam proses pengelolaan data keuangan perusahaan dan dapat mengakses informasi keuangan tanpa harus meminta kepada bagian keuangan.

Kata Kunci: Sistem Informasi Keuangan, Terintegrasi, CodeIgniter, PHP, Oracle.

\section{INTRODUCTION}

Pura Barutama Inc. is a subsidiary of the Pura Group based in Kudus, Central Java, Indonesia which is engaged in printing and packaging. Pura Group currently has 30 production divisions and 13,000 workers and has partnered with various government and private agencies and industries in more than 90 countries. Pura Barutama Inc. always develops its information technology to support current business processes, such as the financial information system. The current financial information system is still desktop-based and centralized only in the finance department, As a result, the Marketing, Taxation, and Purchasing Departments must manually request the Finance Department for financial details such as pre-order reports, accounts receivable balance reports, invoice information, and income tax withholding evidence article 23 ( $\mathrm{PPH} 23$ ). This resulted in obstruction of the transaction process (Loveri, 2018) between the Marketing, Taxation, and Purchasing Departments with customers and suppliers, thereby disrupting business processes (Margaretha \& Nababan, 2020) of Pura Barutama Inc. This is regarded as not optimizing one of the functions of the financial information system, namely increasing the accessibility of existing financial data to users in an effective and efficient manner (Anggraeni \& Irviani, 2017), to simplify the 
process of processing financial data and accessing corporate financial information.

In this study, an integrated web-based financial information system was developed so that the Marketing, Taxation, and Purchasing Departments could more conveniently and effectively access the necessary financial details. Some of the features of this financial information system are: 1) to manage data on outstanding preorders; 2) accounts receivable balance; 3) invoice; 4) data of tax withholding evidence PPH 23. These features support the Marketing and Purchasing Section to view pre-order information, accounts receivable balances, and invoices when making transactions with customers and suppliers without manually asking the Finance Department to speed up the transaction process and reduce errors. In the Taxation Section, this feature helps to manage and display the PPH 23 withholding evidence and sends emails containing evidence of PPH 23 withholding to both customers and suppliers. This information system is designed using object-oriented modeling methods, namely Unified Modeling Language (UML), and is built using the CodeIgniter framework and Oracle database which is directly connected to Pura Barutama Inc. The CodeIgniter Framework has several advantages compared to other frameworks including 1) is open source or free (Destiningrum \& Adrian, 2017); 2) small in size so that it does not require large resources for storage and faster program execution time (Destiningrum \& Adrian, 2017); 3) using the MVC (Model View Controller) concept which allows separation between application-logic and presentation layers so that it is easier for future repairs or maintenance (Destiningrum \& Adrian, 2017) and minimizes repetitive code writing (Heru, 2018); 4) has many libraries (Heru, 2018).

Table 1. Literature Research

\begin{tabular}{|c|c|c|}
\hline \multicolumn{2}{|r|}{ Research Problem } & Literature Supports \\
\hline \multirow[t]{5}{*}{1} & \multirow{5}{*}{$\begin{array}{l}\text { The Marketing, Taxation, and Purchasing } \\
\text { Departments take a long time to see the } \\
\text { company's financial information because } \\
\text { they have to manually request it from the } \\
\text { finance department, which interferes } \\
\text { with the business process for deals with } \\
\text { clients and suppliers where time is of the } \\
\text { essence. }\end{array}$} & $\begin{array}{l}\text { Employees find it inconvenient to process financial report data since } \\
\text { they still depend on the manual system (Yanuardi \& Permana, 2019) }\end{array}$ \\
\hline & & $\begin{array}{l}\text { The business process for recapitulating company financial statements is } \\
\text { done manually which can cause problems due to human errors } \\
\text { (Margaretha \& Nababan, 2020) }\end{array}$ \\
\hline & & $\begin{array}{l}\text { The complexity in creating transaction reports, as well as the slow } \\
\text { process of creating financial data reports, because data management is } \\
\text { mostly done manually for books (Hakim, 2020) }\end{array}$ \\
\hline & & $\begin{array}{l}\text { Transaction management and reporting are still manual, leading to } \\
\text { regular financial transaction processing errors, and take a long time, and } \\
\text { are less efficient (Loveri, 2018) }\end{array}$ \\
\hline & & $\begin{array}{l}\text { Data search and verification are performed manually since Microsoft } \\
\text { Office Excel basic data processing is still used and is not well integrated } \\
\text { (Ritonga \& Hendriyati, 2020) }\end{array}$ \\
\hline \multirow[t]{2}{*}{2} & \multirow{2}{*}{$\begin{array}{l}\text { Access to financial information is only } \\
\text { limited to desktop-based applications and } \\
\text { can only be accessed by the finance } \\
\text { department, so there is a lack of flexibility } \\
\text { from the Marketing, Taxation, and } \\
\text { Purchasing Departments in accessing } \\
\text { financial information. }\end{array}$} & $\begin{array}{l}\text { The previous financial information system was not performing } \\
\text { optimally due to inefficient financial data reporting processes in terms } \\
\text { of time and funds (Zaen et al., 2019) }\end{array}$ \\
\hline & & $\begin{array}{l}\text { Students and student guardians can only view and monitor academic } \\
\text { grades conventionally when distributing report cards only (Anam, } \\
2018 \text { ) }\end{array}$ \\
\hline
\end{tabular}

Results of the research literature in Table 1 show that the problem that many companies, agencies, and organizations often have is that financial data is difficult to handle, especially in the process of recording and financial reports, thereby reducing work efficiency and effectiveness. This issue arises as a result of a human error that occurs during the process of processing financial data, which still employs manual methods such as recording on paper or using a basic data processor such as Microsoft Office Excel. Based on previous research, to overcome this problem is to create a computerized system that can process financial data using a variety of system design methods. In this research, the authors built a web-based financial information system using object-oriented modeling methods, namely Unified Modeling Language (UML). The difference between this study and previous studies is that the financial information system built in this study is not only accessed by the Finance Section but also by the Marketing, Taxation, and Purchasing Department in each division at Pura Barutama Inc. Kudus with different roles for each user. This is a job maximization of the financial system to provide financial data and information integration for each user.

The purpose of this research is the development of a web-based financial information system at Pura Barutama Inc. Kudus. The web-based financial system that was built provides several benefits such as 1) make financial reports easier to create (Yanuardi \& Permana, 2019); 2) provide time efficiency in the processing of financial data in the Finance Section and other divisions that need it (Yanuardi \& Permana, 2019) to increase the efficiency of company performance (Margaretha \& 
Nababan, 2020); 3) facilitate access to financial files and information (Hakim, 2020). The financial information system developed can also make it possible for businesses to manage financial data to quickly integrate the activities in each division, particularly during the process of registration and financial reporting, based on user rights. (Purnomo \& Maknunah, 2018).

\section{MATERIALS AND METHODS}

\section{A. Research Method}

Research generally begins with careful planning, followed by a set of guidelines that are structured logically and systemically for the findings to be present and justifiable. In the development of information systems, a research stage consisting of four phases of research is used, as presented in Picture 1.

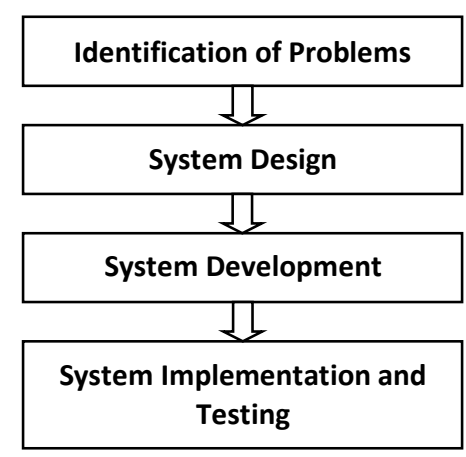

Picture 1. Research Stage

1. Identification of Problems

The earliest stage in this research is problem identification. At this stage, the authors identified the issues that occurred in Pura Barutama Inc. by observing and analyzing the company's business processes and Standard Operating Procedure (SOP), as well as conducting interviews with finance division employees. The issues found were the marketing, taxation, and purchasing departments' lack of efficiency and flexibility in obtaining financial data since the departments had to ask for financial details manually from the finance department. The departments of marketing, taxation, and purchasing are sections that deal directly with customers and suppliers. As a result, the process of obtaining financial information, which is still manual, takes a long time and impedes a company's business processes. The financial information seen is the pre-order report, accounts receivable balance report, invoice information, and evidence of withholding PPH 23.

2. System Design

After the initial stage, the system design was carried out and the problem was identified. At this stage, a new system was designed to address the problems at Pura Barutama Inc. The design was carried out using object-oriented modeling methods, namely UML, which includes use case diagrams, class diagrams, activity diagrams, and sequence diagrams.

UML is a standard language that is widely used to define, analyze and design, and describe object-oriented programming architectures in the industrial world. UML is a computer modeling and visual communication language that uses diagrams and text support and the use of UML is not only limited to one method but is mostly used in objectoriented methodologies (Rambe et al., 2020).

3. System Development

At this stage, the development or manufacture of a system constructed in the previous stage was completed. This web-based financial information system was built with the PHP programming language version 7.2.3 using the CodeIgniter framework version 3.1.11 and an Oracle database which is directly connected to Pura Barutama Inc. and supported by several PHP libraries and javascript libraries.

4. System Implementation and Testing

System testing was performed after the system has been completed to see whether the system has run according to the design being performed. The system testing used the black box testing method which is one of the software testing techniques. Black box testing was used to determine the functionality of an application. The main focus of black-box testing is the input available for an application and the expected output for each input value (Verma et al., 2017).

\section{B. Data Collection Technique}

The data collection technique used in this study was interviews conducted with several sources from the Marketing, Taxation, and Purchasing Department at Pura Barutama Inc. The questions address the limitations, difficulties, or problems encountered when carrying out business processes, particularly those involving the reporting of company financial data.

\section{RESULTS AND DISCUSSION}

\section{A. Use Case Diagram}

A use case is a diagram that describes or depicts a scenario between the user and the system. Use case also explains what functions are in a system and who are the actors who have the right to access these functions (Hendini, 2016). This use case diagram was created as an initial analysis of system development and describes system functions clearly from the user's perspective. In this financial information system, a user will be given menu access rights by a user who has access rights 
to access the user management menu and access. So each user will have different rights to access the menu. Users who will later use this system are from the marketing, taxation, and purchasing departments managed by the finance department. Picture 2 shows it in greater detail.

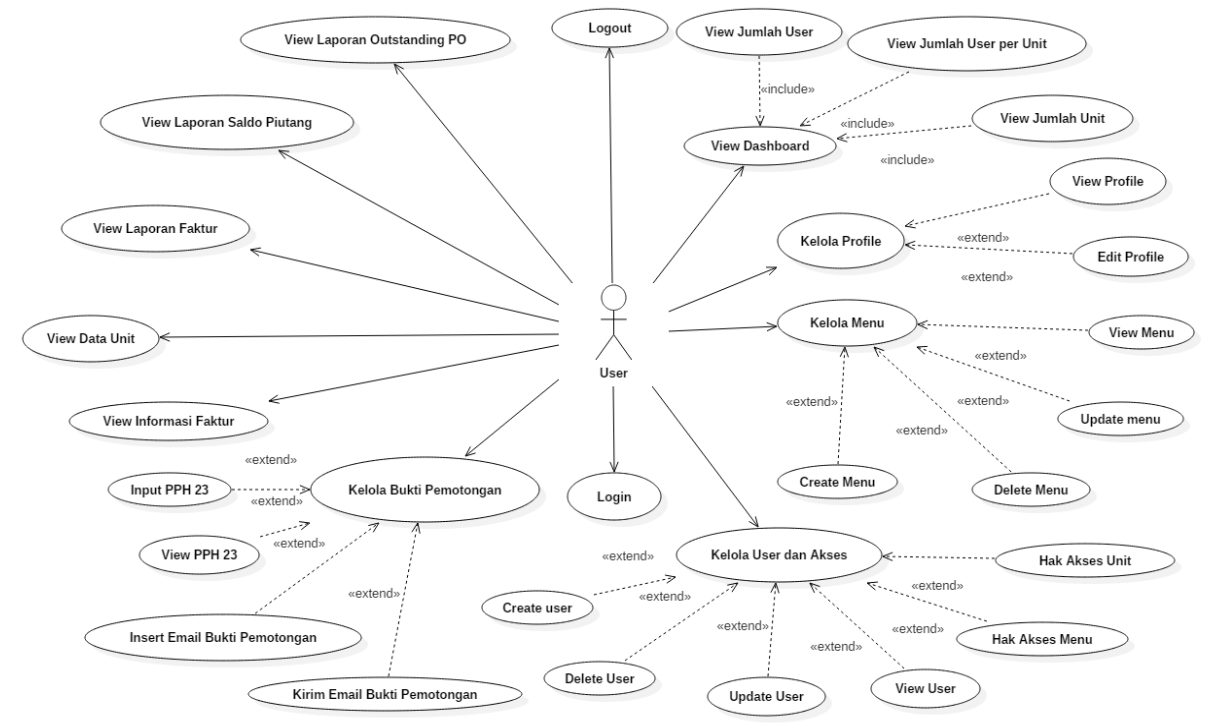

Picture 2. Use Case Diagram

\section{B. Class Diagram}

This class diagram defines the structure of a system in terms of describing the classes that will be used to construct the system, with the class consisting of three major areas, namely names, attributes, and operations (Suendri, 2019). This web-based financial information system was built with the CodeIgniter framework that uses the MVC concept. However, since classes only exist in the model and controller, the MVC concept cannot be explained in the class diagram section. Picture 3 describes it in greater detail.

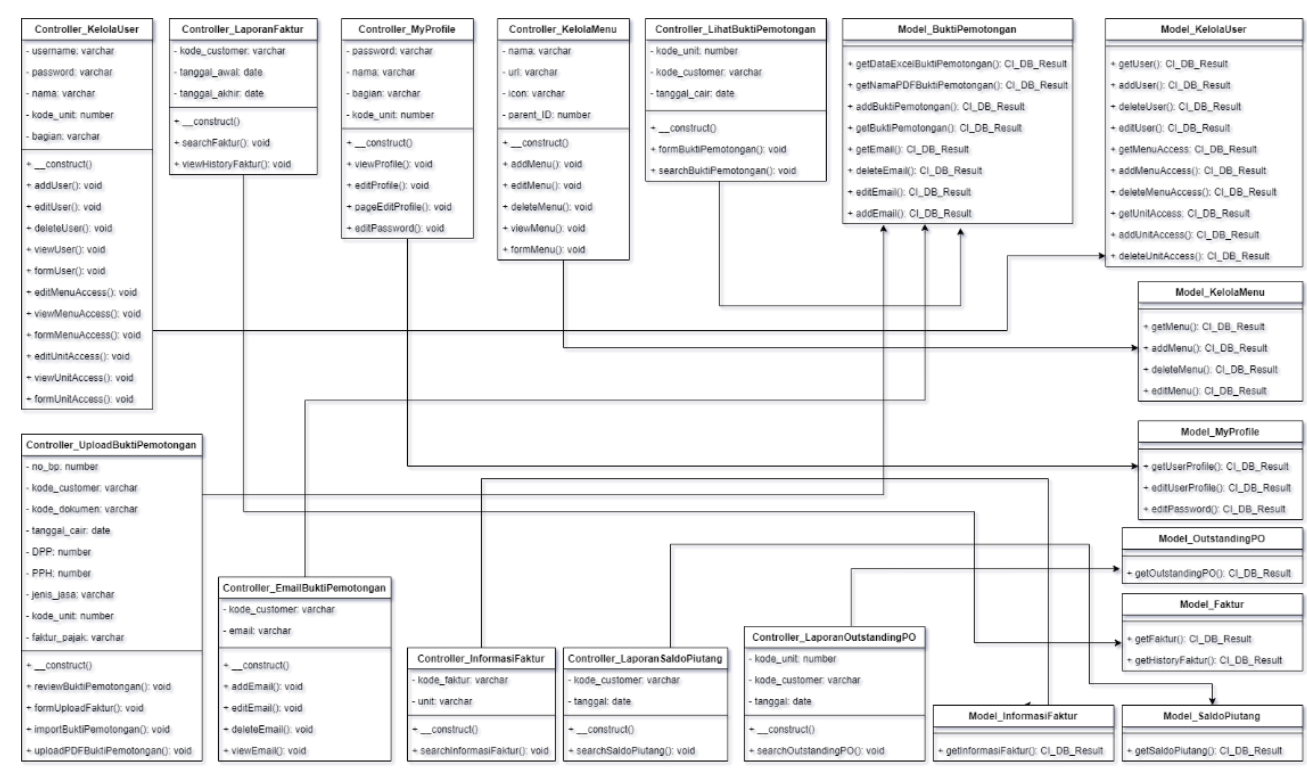

Picture 3. Class Diagram

\section{Activity Diagram}

Activity diagrams are diagrams that describe the workflow or activity in a system (Ayu \& Permatasari, 2018) ) that will be carried out. This activity diagram is a derivative or created based on a use case diagram. One of the activity diagrams that explains the workflow from the menu, view outstanding pre-orders, is described in Picture 4. 


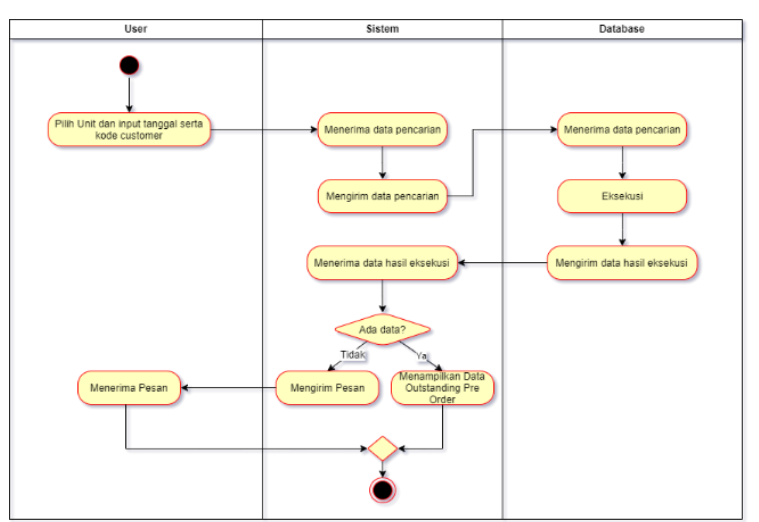

Picture 4. Activity Diagram View Outstanding Pre-Order

\section{Sequence Diagram}

Sequence diagrams are diagrams that describe how a function or operation is carried out from collaboration or interaction between objects (Rinaldi, 2019). The MVC concept in Codelgniter is described in Picture 5 regarding the execution of the feature to find accounts receivable balances.

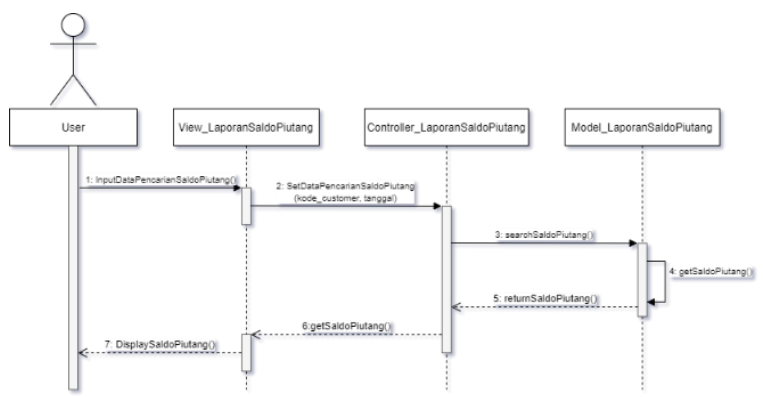

Picture 5. Sequence Diagram Cari Saldo Piutang

\section{E. System Implementation}

At this stage, the design that has been made into a system was carried out. Some of the interfaces for the Pura Inc. financial information system that have been built are as follows:

1. Form Login Page

Picture 6 is a login form page display that appears when the user wants to enter the main menu. To access the main menu, the user must first fill out the username and password that the administrator has set up.

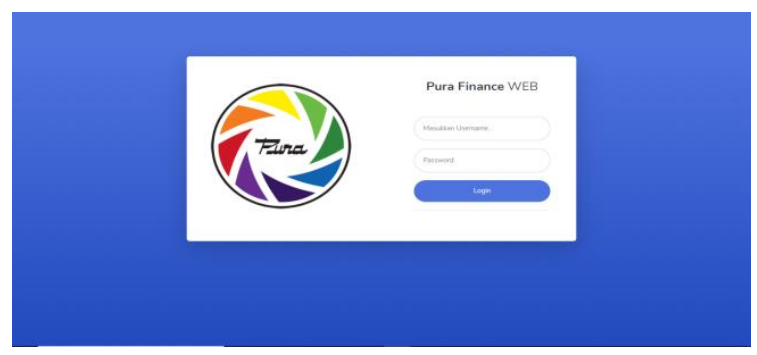

Picture 6. Form Login Page

2. My Profile Menu Page
Picture 7 is a display of my profile menu page, which is the first menu displayed when entering the financial information system. My profile menu page displays information about the user consisting of name, username, section, and unit. Users can change the password on the change password button and change the profile on the edit profile button.

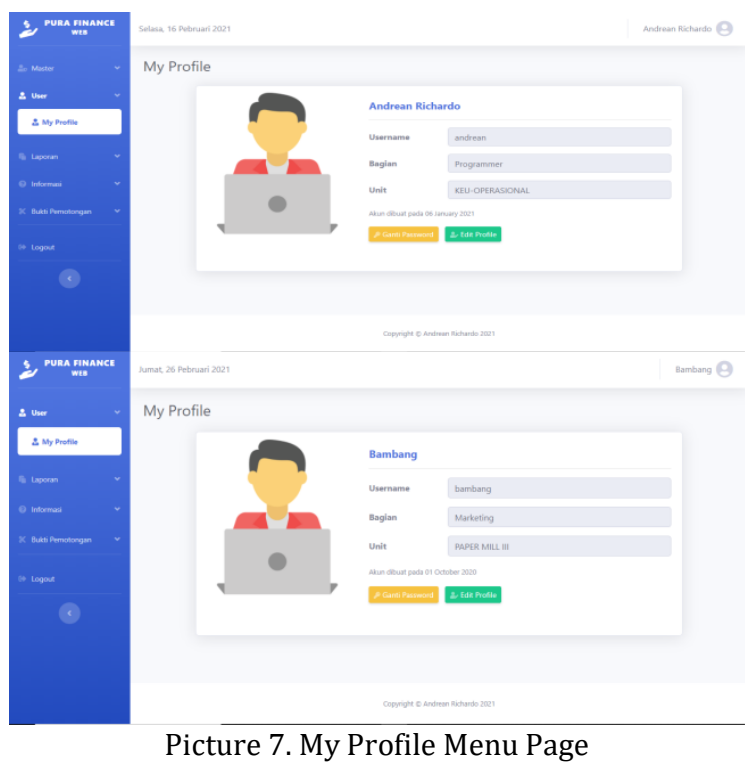

3. Kelola User dan Akses Menu Page

Picture 8 is a "kelola user" and akses menu page that displays users who have registered in the financial information system. In the "kelola user" and "akses user" menu, there is a "tambah user baru" button to add new users, "hapus user" button to delete users, "edit users" button to change user data, "hak akses menu" button to change useraccessible menu lists, and "hak akses unit" to change the unit list user accessible on the "bukti pemotongan" menu.

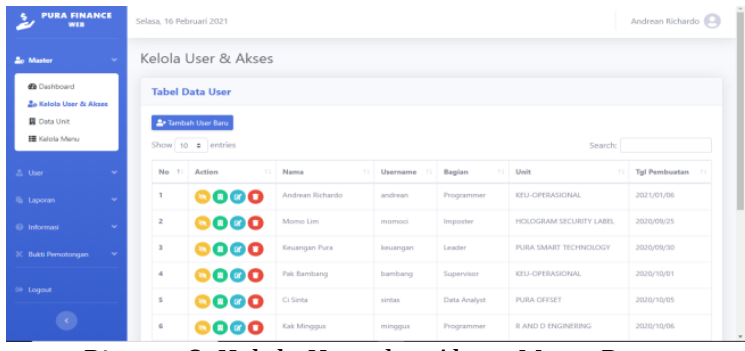

Picture 8. Kelola User dan Akses Menu Page

4. Laporan Saldo Piutang Menu Page

Picture 9 is the "laporan saldo piutang" menu page that displays the accounts receivable balance report according to the customer code and date entered by the user in the search form. Accounts receivable balance reports displayed can be imported in excel, pdf, CSV and can be printed immediately. 


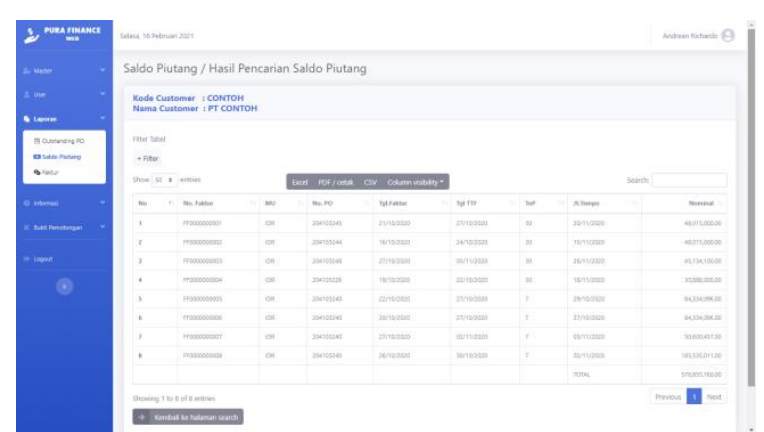

Picture 9. Laporan Saldo Piutang Menu Page

\section{Upload Bukti Potong Menu Page}

Picture 10 is a "upload bukti potong" menu page that is useful for uploading proof of withholding PPH 23 in excel and pdf file formats. The user can check again whether or not the data that is to be uploaded is valid on the preview page before data is uploaded into the database. Data cannot be uploaded if the data entered is invalid or not by the predetermined format.

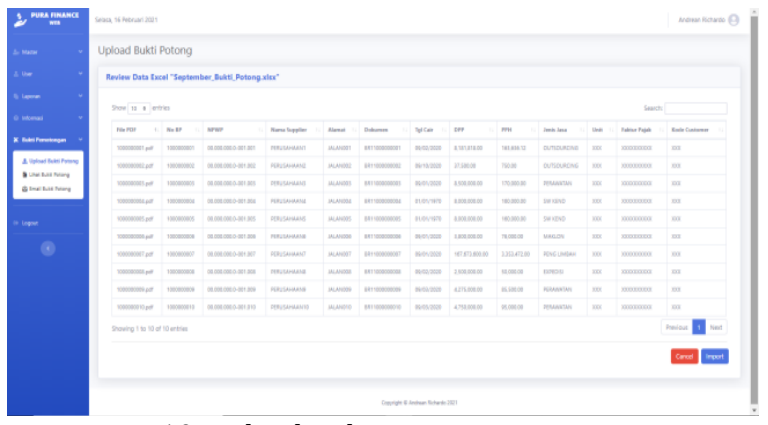

Picture 10. Upload Bukti Pemotongan Menu Page

\section{Lihat Bukti Potong Menu Page}

Picture 11 is a "lihat bukti potong" menu page that displays proof of withholding of PPH 23 according to the unit, customer code, and time period entered by the user in the search form. The user can then view the pdf file of the PPH 23 withholding evidence and send an email containing the selected pdf file to the customer by pressing the send button.

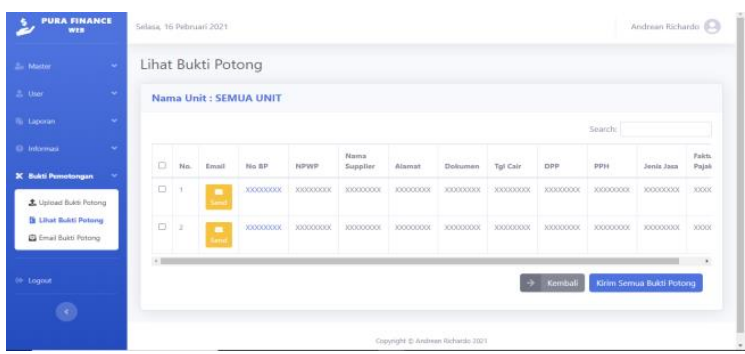

Picture 11. Lihat Bukti Potong Menu Page

\section{F. System Testing}

The system testing was carried out using the black box testing method which is one of the software testing techniques. Black box testing is used to determine the functional specifications of an application (Bangkalang, 2019). The main focus of black-box testing is the input available for an application and the expected output for each input value (Rambe et al., 2020). The results of testing the financial information system built with black box testing can be seen in Table 2 .

Table 2. Black Box Testing Results

\begin{tabular}{|c|c|c|c|c|}
\hline Function Tested & Condition & Expected Output & $\begin{array}{c}\text { Output Generated by The } \\
\text { System }\end{array}$ & Status \\
\hline \multirow[t]{3}{*}{ Login } & $\begin{array}{l}\text { Correct username and } \\
\text { password }\end{array}$ & $\begin{array}{l}\text { The system accepts login access } \\
\text { then adds a session and goes to my } \\
\text { profile page }\end{array}$ & $\begin{array}{l}\text { The system accepts login access } \\
\text { then adds a session and goes to my } \\
\text { profile page }\end{array}$ & Valid \\
\hline & Incorrect username & $\begin{array}{l}\text { The system denies login access and } \\
\text { displays a message "Username } \\
\text { tidak terdaftar" }\end{array}$ & $\begin{array}{l}\text { The system denies login access } \\
\text { and displays a message } \\
\text { "Username tidak terdaftar" }\end{array}$ & Valid \\
\hline & $\begin{array}{l}\text { Correct username and } \\
\text { incorrect password }\end{array}$ & $\begin{array}{l}\text { The system denies login access and } \\
\text { displays a message } \\
\text { "Password Anda salah" }\end{array}$ & $\begin{array}{l}\text { The system denies login access } \\
\text { and displays a message "Password } \\
\text { Anda salah" }\end{array}$ & Valid \\
\hline Display Dashboard & & The system displays data & The system displays data & Valid \\
\hline Display Unit Data & & The system displays data & The system displays data & Valid \\
\hline Display User Data & & The system displays data & The system displays data & Valid \\
\hline \multirow[t]{2}{*}{ Add User Data } & Form filled correctly & $\begin{array}{l}\text { The system adds data and displays } \\
\text { messages } \\
\text { "User berhasil ditambahkan" }\end{array}$ & $\begin{array}{l}\text { The system adds data and displays } \\
\text { messages } \\
\text { "User berhasil ditambahkan" }\end{array}$ & Valid \\
\hline & $\begin{array}{l}\text { Input the username that has } \\
\text { been registered in the } \\
\text { database }\end{array}$ & $\begin{array}{l}\text { The system failed to add data and } \\
\text { displays messages } \\
\text { "Username sudah dipakai" }\end{array}$ & $\begin{array}{l}\text { The system failed to add data and } \\
\text { displays messages } \\
\text { "Username sudah dipakai" }\end{array}$ & Valid \\
\hline \multirow[t]{2}{*}{ Change User Data } & Form filled correctly & $\begin{array}{l}\text { The system changes data and } \\
\text { displays messages } \\
\text { "Data user berhasil diubah" }\end{array}$ & $\begin{array}{l}\text { The system changes data and } \\
\text { displays messages } \\
\text { "Data user berhasil diubah" }\end{array}$ & Valid \\
\hline & $\begin{array}{l}\text { Input the username that has } \\
\text { been registered in the } \\
\text { database }\end{array}$ & $\begin{array}{l}\text { The system failed to change data } \\
\text { and displays messages } \\
\text { "Username sudah dipakai" }\end{array}$ & $\begin{array}{l}\text { The system failed to change data } \\
\text { and displays messages } \\
\text { "Username sudah dipakai" }\end{array}$ & Valid \\
\hline Delete User Data & $\begin{array}{l}\text { The data to be deleted is } \\
\text { selected }\end{array}$ & $\begin{array}{l}\text { The system deletes data and } \\
\text { displays a message } \\
\text { "User berhasil dihapus" }\end{array}$ & $\begin{array}{l}\text { The system deletes data and } \\
\text { displays a message } \\
\text { "User berhasil dihapus" }\end{array}$ & Valid \\
\hline Change Menu Access Data & $\begin{array}{l}\text { Choose a menu list that can } \\
\text { be accessed by the user }\end{array}$ & $\begin{array}{l}\text { The system changes data and } \\
\text { displays messages }\end{array}$ & $\begin{array}{l}\text { The system changes data and } \\
\text { displays messages }\end{array}$ & Valid \\
\hline
\end{tabular}




\begin{tabular}{|c|c|c|c|c|}
\hline Function Tested & Condition & Expected Output & $\begin{array}{c}\text { Output Generated by The } \\
\text { System }\end{array}$ & Status \\
\hline & & "Data akses menu berhasil diubah" & "Data akses menu berhasil diubah" & \\
\hline Change Unit Access Data & $\begin{array}{l}\text { Choose a unit list that can be } \\
\text { accessed by the user }\end{array}$ & $\begin{array}{l}\text { The system changes data and } \\
\text { displays messages } \\
\text { "Data akses unit berhasil diubah" }\end{array}$ & $\begin{array}{l}\text { The system changes data and } \\
\text { displays messages } \\
\text { "Data akses unit berhasil diubah" }\end{array}$ & Valid \\
\hline Displat Menu Data & & The system displays data & The system displays data & Valid \\
\hline Add Menu Data & Form filled correctly & $\begin{array}{l}\text { The system adds data and displays } \\
\text { messages } \\
\text { "Menu berhasil ditambahkan" }\end{array}$ & $\begin{array}{l}\text { The system adds data and displays } \\
\text { messages } \\
\text { "Menu berhasil ditambahkan" }\end{array}$ & Valid \\
\hline Change Menu Data & Form filled correctly & $\begin{array}{l}\text { The system changes data and } \\
\text { displays messages } \\
\text { "Data menu berhasil diubah" }\end{array}$ & $\begin{array}{l}\text { The system changes data and } \\
\text { displays messages } \\
\text { "Data menu berhasil diubah" }\end{array}$ & Valid \\
\hline Delete Menu Data & $\begin{array}{l}\text { The data to be deleted is } \\
\text { selected }\end{array}$ & $\begin{array}{l}\text { The system deletes data and } \\
\text { displays a message } \\
\text { "Menu berhasil dihapus" }\end{array}$ & $\begin{array}{l}\text { The system deletes data and } \\
\text { displays a message } \\
\text { "Menu berhasil dihapus" }\end{array}$ & Valid \\
\hline Display My Profile & & The system displays data & The system displays data & Valid \\
\hline Change Password Data & Form filled correctly & $\begin{array}{l}\text { The system changes data and } \\
\text { displays messages } \\
\text { "Password berhasil diubah" }\end{array}$ & $\begin{array}{l}\text { The system changes data and } \\
\text { displays messages } \\
\text { "Password berhasil diubah" }\end{array}$ & Valid \\
\hline Change Profile Data & Form filled correctly & $\begin{array}{l}\text { The system changes data and } \\
\text { displays messages } \\
\text { "Data berhasil diubah" }\end{array}$ & $\begin{array}{l}\text { The system changes data and } \\
\text { displays messages } \\
\text { "Data berhasil diubah" }\end{array}$ & Valid \\
\hline \multirow{2}{*}{$\begin{array}{l}\text { Search Outstanding Pre- } \\
\text { Order Reports Data }\end{array}$} & Data found & The system displays data & The system displays data & Valid \\
\hline & Data not found & $\begin{array}{l}\text { The system failed to display data } \\
\text { and displays messages } \\
\text { "Data Outstanding Pre-order tidak } \\
\text { ditemukan" }\end{array}$ & $\begin{array}{l}\text { The system failed to display data } \\
\text { and displays messages } \\
\text { "Data Outstanding Pre-order tidak } \\
\text { ditemukan" }\end{array}$ & Valid \\
\hline \multirow{2}{*}{$\begin{array}{l}\text { Search Accounts } \\
\text { Receivable Balance } \\
\text { Reports Data }\end{array}$} & Data found & The system displays data & The system displays data & Valid \\
\hline & Data not found & $\begin{array}{l}\text { The system failed to display data } \\
\text { and displays messages } \\
\text { "Data Saldo Piutang tidak } \\
\text { ditemukan" }\end{array}$ & $\begin{array}{l}\text { The system failed to display data } \\
\text { and displays messages } \\
\text { "Data Saldo Piutang tidak } \\
\text { ditemukan" }\end{array}$ & Valid \\
\hline \multirow{2}{*}{$\begin{array}{l}\text { Search Invoice Reports } \\
\text { Data }\end{array}$} & Data found & The system displays data & The system displays data & Valid \\
\hline & Data not found & $\begin{array}{l}\text { The system failed to display data } \\
\text { and displays messages } \\
\text { "Data Faktur tidak ditemukan" }\end{array}$ & $\begin{array}{l}\text { The system failed to display data } \\
\text { and displays messages } \\
\text { "Data Faktur tidak ditemukan" }\end{array}$ & Valid \\
\hline \multirow{2}{*}{$\begin{array}{l}\text { Search Invoice } \\
\text { Information Data }\end{array}$} & Data found & The system displays data & The system displays data & Valid \\
\hline & Data not found & $\begin{array}{l}\text { The system failed to display data } \\
\text { and displays messages "Nomor } \\
\text { Faktur tidak ditemukan" }\end{array}$ & $\begin{array}{l}\text { The system failed to display data } \\
\text { and displays messages } \\
\text { "Nomor Faktur tidak ditemukan" }\end{array}$ & Valid \\
\hline \multirow[t]{4}{*}{$\begin{array}{l}\text { Upload Income Tax Article } \\
23 \text { Data }\end{array}$} & Form filled correctly & $\begin{array}{l}\text { The system displays data preview } \\
\text { page before importing it to the } \\
\text { database }\end{array}$ & $\begin{array}{l}\text { The system displays data preview } \\
\text { page before importing it to the } \\
\text { database }\end{array}$ & Valid \\
\hline & $\begin{array}{l}\text { Data does not match the } \\
\text { requirements on the } \\
\text { preview page }\end{array}$ & $\begin{array}{l}\text { The import button cannot be } \\
\text { clicked }\end{array}$ & $\begin{array}{l}\text { The import button cannot be } \\
\text { clicked }\end{array}$ & Valid \\
\hline & $\begin{array}{l}\text { Data match with the } \\
\text { requirement }\end{array}$ & The import button can be clicked & The import button can be clicked & Valid \\
\hline & Click the button "Import" & The system adds data & The system adds data & Valid \\
\hline \multirow{2}{*}{$\begin{array}{l}\text { Search Income Tax Article } \\
\text { 23 Data }\end{array}$} & Data found & The system displays data & The system displays data & Valid \\
\hline & Data not found & $\begin{array}{l}\text { The system failed to display data } \\
\text { and displays messages } \\
\text { "Data Bukti Pemotongan tidak } \\
\text { ditemukan" }\end{array}$ & $\begin{array}{l}\text { The system failed to display data } \\
\text { and displays messages } \\
\text { "Data Bukti Pemotongan tidak } \\
\text { ditemukan" }\end{array}$ & Valid \\
\hline $\begin{array}{l}\text { Send Email Containing } \\
\text { Proof of Income Tax } \\
\text { Article } 23 \text { in PDF File } \\
\end{array}$ & Click the button "Send" & $\begin{array}{l}\text { The system sends an email } \\
\text { containing proof of income tax } \\
\text { article } 23 \text { in a PDF file }\end{array}$ & $\begin{array}{l}\text { The system sends an email } \\
\text { containing proof of income tax } \\
\text { article } 23 \text { in a PDF file } \\
\end{array}$ & Valid \\
\hline Display Email Data & & The system displays data & The system displays data & Valid \\
\hline Add Email Data & Form filled correctly & $\begin{array}{l}\text { The system adds data and displays } \\
\text { messages } \\
\text { "Email berhasil ditambahkan" }\end{array}$ & $\begin{array}{l}\text { The system adds data and displays } \\
\text { messages } \\
\text { "Email berhasil ditambahkan" }\end{array}$ & Valid \\
\hline Change Email Data & Form filled correctly & $\begin{array}{l}\text { The system changes data and } \\
\text { displays messages } \\
\text { "Data email berhasil diubah" }\end{array}$ & $\begin{array}{l}\text { The system changes data and } \\
\text { displays messages } \\
\text { "Data email berhasil diubah" }\end{array}$ & Valid \\
\hline Delete Email Data & $\begin{array}{l}\text { The data to be deleted is } \\
\text { selected }\end{array}$ & $\begin{array}{l}\text { The system deletes data and } \\
\text { displays a message } \\
\text { "Email berhasil dihapus" }\end{array}$ & $\begin{array}{l}\text { The system deletes data and } \\
\text { displays a message } \\
\text { "Email berhasil dihapus" }\end{array}$ & Valid \\
\hline
\end{tabular}

\section{CONCLUSION}

The result of this research is the web-based Financial Information System at Pura Barutama
Inc. which was built using the CodeIgniter framework and Oracle database. Based on the discussion, with the financial information system that has been built, the Marketing Section, the 
Taxation Section, and the Purchasing Section can view information of outstanding pre-orders, accounts receivable balances, invoices, and PPH 23 withholding tax data. Also, the Marketing Department, the Taxation Department, and the Purchasing Department can access financial information that relates directly to customers without having to manually request information from the finance department.

\section{REFERENCE}

Anam, K. (2018). Analisa Dan Perancangan Sistem Informasi Akademik Berbasis Web Pada Mi Al-Mursyidiyyah Al-'Asyirotussyafi'iyyah. Jurnal Teknik Informatika, 11(2). https://doi.org/10.15408/jti.v11i2.8867

Anggraeni, E. Y., \& Irviani, R. (2017). Pengantar Sistem Informasi (E. Risanto (ed.); 1st ed.). CV.Andi Offset.

Ayu, F., \& Permatasari, N. (2018). Perancangan Sistem Informasi Pengolahan Data Praktek Kerja Lapangan (PKL) Pada Devisi Humas Pt. Pegadaian. Intra-Tech, 2(2).

Bangkalang, D. H. (2019). Pembangunan Aplikasi Monitoring Kinerja Surveyor Produk Kredit Bank XYZ Berdasarkan Tahapan Engineering Development. CESS (Journal of Computer Engineering System and Science), 4(2), 258265.

Destiningrum, M., \& Adrian, Q. J. (2017). Sistem Informasi Penjadwalan Dokter Berbassis Web Dengan Menggunakan Framework Codeigniter (Studi Kasus: Rumah Sakit Yukum Medical Centre). Jurnal Teknoinfo, 11(2),

30. https://doi.org/10.33365/jti.v11i2.24

Hakim, L. (2020). Perancangan Sistem Informasi Pengolahan Data Keuangan Berbasis Web Responsive Pada Butik Nisa Syar'i Lubuklinggau. Jurnal Digital Teknologi Informasi, $3(1), \quad 14$. https://doi.org/10.32502/digital.v3i1.2498

Hendini, A. (2016). Pemodelan UML Sistem Informasi Monitoring Penjualan dan Stok Barang (Studi Kasus: Distro Zhezha Pontianak). Jurnal Khatulistiwa Informatika, IV(2), 107-116.

Heru, S. (2018). Coding Mudah dengan CodeIgniter, JQuery, Bootstrap, dan Datatable. In Coding Mudah dengan CodeIgniter, JQuery, Bootstrap, dan Datatable. Elex Media Komputindo.

Loveri, T. T. (2018). Sistem Informasi Aplikasi Pengelolaan Transaksi Keuangan Dan Pendataan Konsumen Pada Cv. Puplas. Jurnal
Sains Dan Informatika, 4(2). https://doi.org/10.22216/jsi.v4i2.3584

Margaretha, H. A., \& Nababan, M. N. (2020). Perancangan Sistem Informasi Keuangan Berbasis Web Studi Kasus PT. Karya Swadaya Abadi. Jurnal Madani: Ilmu Pengetahuan, Teknologi, Dan Humaniora, 1(2), 24-31.

Purnomo, H., \& Maknunah, J. (2018). Sistem Informasi Pengolahan Data Keuangan Berbasis Web. J I M P - Jurnal Informatika Merdeka Pasuruan, 3(3), 44-49. https://doi.org/10.37438/jimp.v3i3.187

Rambe, B. H., Pane, R., Irmayani, D., Nasution, M., \& Munthe, I. R. (2020). UML Modeling and Black Box Testing Methods in the School Payment Information System. Jurnal Mantik, 4(3), 1634-1640.

https://doi.org/10.35335/MANTIK.VOL4.20 20.969.PP1634-1640

Rinaldi, R. (2019). Penerapan Unified Modelling Language (UML) Dalam Analisis Dan Perancangan Aplikasi E-Learning. Jurnal SIMTIKA, 2(1).

Ritonga, R. A., \& Hendriyati, P. (2020). Sistem Informasi Administrasi Keuangan Berbasis Web Menggunakan Framework Laravel Pada Smk Yp FATAHILLAH 2. Universitas Banten Jaya, 4(1), 35-47.

Suendri, S. (2019). Implementasi Diagram UML (Unified Modelling Language) Pada Perancangan Sistem Informasi Remunerasi Dosen Dengan Database Oracle (Studi Kasus: UIN Sumatera Utara Medan). Algoritma: Jurnal Ilmu Komputer Dan Informatika, 2(2), $1-9$.

http://jurnal.uinsu.ac.id/index.php/algoritm a/article/view/3148

Verma, A., Khatana, A., \& Chaudhary, S. (2017). A Comparative Study of Black Box Testing and White Box Testing. International Journal of Computer Sciences and Engineering, 5(12), 301-304. https://doi.org/10.26438/ijcse/v5i12.3013 04

Yanuardi, Y., \& Permana, A. A. (2019). RANCANG Bangun Sistem Informasi Keuangan Pada Pt. Secret Discoveries Travel And Leisure Berbasis Web. JIKA (Jurnal Informatika). https://doi.org/10.31000/.v2i2.1513

Zaen, M. T. A., Julkarnaen, J., \& Saleh, M. (2019). Sistem Informasi Keuangan Pada Dinas Perhubungan Kabupaten Lombok Tengah Berbasis Web. Jurnal Manajemen Informatika Dan Sistem Informasi, 2(1), 50. https://doi.org/10.36595/misi.v2i1.79 